\title{
A Study on Customer Satisfaction towards Banking Service
}

\author{
M. Chandrasekaran ${ }^{1}$ and S. Prasath ${ }^{2}$ \\ ${ }^{1}$ Director \& Research Advisor, Department of Management, \\ Dhanalakshmi Srinivasan College of Arts and Science for Women, Perambalur, Tamil Nadu, India \\ ${ }^{2}$ Assistant Professor \& Ph.D. Research Scholar, Department of Management Studies, \\ Dhanalakshmi Srinivasan Engineering College, Perambalur, Tamil Nadu, India \\ E-Mail: drchandrasekaran@gmail.com
}

\begin{abstract}
This study can be analyse the customers' satisfaction towards the banking services rendered by the SBI in Tiruchirappalli District. The researcher conducted a literature search on banking services of SBI interviewing of its 50 customers and thoroughly scrutinized how it caters to the banking needs of the inhabitants of Tiruchirappalli district. The study also focused on various factors that determine the customers' satisfaction like employees' behaviour, banking services, banking performance, infra- structure facility, loan oriented services and other value added services. Analysis was made by using various tools like percentage Analysis, Chi- Square Test and charts. The result showed that there is a significant relationship between the variable of customer satisfaction and banking services of the SBI and the customers have a medium level of satisfaction. The SBI could consider the researcher's suggestions in order to alleviate its reputation and customer satisfaction.
\end{abstract}

Keywords: Customers' Satisfaction, Customer perception, Banking services, Products

\section{INTRODUCTION}

Undoubtedly most industries and businesses persistently endeavour to maximize customer value. Nonetheless this has globally become the hub of marketing for every organization or industry. In as much as possible for any company to probably reach this end would require the need to achieve absolute customer satisfaction through offering incomparable services to customers. Indeed Customer service is the ability to identify the needs of customers and meeting those needs beyond their expectation within the shortest possible time. In this light the focus of marketing is to address the customers' needs, wants, preference and attitudes.

Arguably, marketing concepts posit that the right avenue to start the search for new products ideas are the customers' needs and wants Kotler (1991). The banking industries in India continue to attract, retain and maintain qualified personnel to fill their most sensitive positions to have customer confidence, credibility, and trustworthiness and be more attractive to customers. If these claims are to hold, then it is worth investigating the importance of customer service in the Indian banking industry.

\section{IMPORTANCE OF CUSTOMER SERVICE}

Service quality has been viewed as a significant issue in the banking industry by Stafford (1994). Since banking services are generally characterized with undifferentiated products, it becomes imperative for banks to strive for improved service quality if they want to distinguish themselves from the competition. Positive relationship between high levels of service quality and improved financial performance has been established by Roth and van der Velde (1991) and, Bennet (1992). Similarly, Bowen and Hedges (1993) documented that improvement in quality of service is related to expansion of market share. In the current marketing literature, much attention on the issue of service quality as related to customers' attitudes towards services is focused on the relationship between customer expectations of a service and the perceptions of the quality of provision. This relationship known as perceived service quality was first introduced by Gronroos (1982). Gronroos suggested that the perceived quality of a given service is the result of an evaluation process since consumer makes comparison between the services they expect with perceptions of the services they receive. Hence, he concluded that the quality of service is dependent on two variables: expected service and perceived service. Parasuraman et al. (1985) considered that a customer's assessment of overall service quality depends on the gap between the expected and perceived service. Thus, the key to managing perceived service quality is to minimize this gap. Zeithaml (1988) defined perceived service quality as the customers' assessment of the overall excellence of the service. Cina (1990) posited that for a smooth implementation of customer care programmes, specific conditions must be set, done and fulfilled. These are: total staff involvement, support from top management, outlining customer requirements and obligations, adherence to set down principles and modes of measuring the set goals.

\section{SIGNIFICANCE OF THE STUDY}

This study empirically examines the importance of customer service in the banking industry. Indeed, an efficient customer service holds the key to overcoming the stiff competition in the banking industry in Tamil Nadu. Not only this but also, customers will be galvanized to advertise the products of that bank through word-of-mouth. These could be achieved if the bottlenecks associated with 
effective customer service delivery are reduced to the barest minimum if not totally eliminated.

\section{OBJECTIVES OF THE STUDY}

1. To evaluate the customer perception towards SBI bank, Tiruchirappalli district.

2. To find out the product range SBI has for its customers.

3. To find out whether customers are satisfied with the product available in SBI

\section{METHODS AND MATERIALS}

Sample sizes of 50 determinations were guided by cost and time consideration, the population size is State Bank of India, Tiruchirappalli. Given the nature of the clientele of the bank, a convenient sample of 50 respondents was selected for the study however the response rate was $85 \%$. This research applied a convenience research sampling method as it appears most suitable considering the characteristics of the study population. Random sampling was further used to select the respondents. Respondents were contacted and they were willing and available to participate in the study hence the use of convenience method was apparent.

\section{DATA ANALYSIS AND INTERPRETATION}

TABle I Socio-Economic Profile Of The Respondents

\begin{tabular}{|l|c|c|}
\hline \multicolumn{1}{|c|}{ Variables } & $\begin{array}{c}\text { No. of Respondents } \\
\text { (n=50) }\end{array}$ & $\begin{array}{c}\text { Percentage } \\
(\mathbf{1 0 0 \% )}\end{array}$ \\
\hline \multicolumn{3}{|c|}{ Gender } \\
\hline Male & 42 & 84 \\
\hline Female & 08 & 16 \\
\hline \multicolumn{3}{|c|}{ Age } \\
\hline Below 30yrs & 39 & 78 \\
\hline Above 30yrs & 11 & 22 \\
\hline \multicolumn{3}{|c|}{ Duration of Customer } \\
\hline Below 2yrs & 19 & 38 \\
\hline 3 to 5yrs & 10 & 20 \\
\hline 6yrs \& above & 21 & 42 \\
\hline
\end{tabular}

Percentage analysis table shows that majorities (84 per cent) were male and remaining 16 per cent were female. Vast majorities (78 per cent) of the respondents were below $30 y r s$ of age group and remaining 22 per cent were above $30 \mathrm{yrs}$. More than half (42 per cent) of the respondents were above 6yrs of customers, 38 per cent were below 2 yrs of customers and remaining 20 per cent were 3 to 5 yrs.

Research Hypothesis: There is no significant difference between customer account operation duration and their overall service satisfaction.

The below one-way ANOVA ' $f$ ' test table indicates that mean and S.D values of below 2 yrs $21.31 \pm 0.518,3$ to $5 \mathrm{yrs}$ $20.12 \pm 0.679$ and remaining $6 y r s$ \& above $21.35 \pm 0.871$.
TABLE II ONE-WAy ANOVA DifFERENCE BETWEen CUSTOMER ACCOUNT OPERATION DURATION AND THEIR OVERALl SERVICE SATISFACTION

\begin{tabular}{|c|c|c|c|}
\hline $\begin{array}{c}\begin{array}{c}\text { Overall Customer } \\
\text { Satisfaction }\end{array} \\
\end{array}$ & Mean & S.D. & $\begin{array}{l}\text { Statistical } \\
\text { inference }\end{array}$ \\
\hline Below 2yrs & 21.31 & 0.518 & \multirow{3}{*}{$\begin{array}{c}\mathrm{F}=3.932 \\
0.117>0.05 \\
\text { Not Significant }\end{array}$} \\
\hline 3 to $5 y r s$ & 20.12 & 0.679 & \\
\hline 6yrs \& above & 21.35 & 0.871 & \\
\hline
\end{tabular}

Therefore, there is no significant difference between customer preferable goods and their overall customer satisfaction. The calculated value is greater than table value $(0.117>0.05)$. The research hypothesis is accepted.

\section{CONCLUSION AND RECOMMENDATION}

Based on the findings and other observation made, the researchers recommended that continuous improvement of the quality of human resources through on the job training is needed. Classify Customer Complaints: as individual complaints are recorded, the nature of the complaint, along with the product or service the complaint is about, requires classification. In the banking sector, complaints that violate federal laws, or internal bank policies and procedures, should be classified separately from other customer service issues. Bank must improve its physical infrastructure such as buildings, furniture, fittings, equipments, vehicles and many to appeal customers since some customers consider them to enhance customer satisfaction. Finally, bank officials in all departments of the Bank must be given customer service training to get the understanding of how important customers are to the bank and also an independent unit should be created to handle creation, implementation monitoring and control of customer service strategies of SBI.

\section{REFERENCES}

[1] Alam, M. and Khokhar, R. (2006). Impact of Internet on Customer Loyalty in Swedish Banks. J. Econ. Psychol., 16, 311-29.

[2] Anderson, E.W. and Sullivan, M. (1993). The antecedents and consequences of consumer satisfaction for firms. Mark. Sci., 12, 12543.

[3] Beerli, A., Martin J. D. and Quintana, A. (2004). A model of customer loyalty in the retail banking market. Eur. J. Mark, 38(1/2), pp. 253-275.

[4] Bennet, R. (1992). The Customer-Driven Competitive Edge: Bank Marketing. 50-51.

[5] Bowen, and Schneider, (1988). Capitalising on Customers. Vikas Publishing: House PVT Limited, New Delhi, pp.53-75

[6] Kim, K. (2004). Conceptualizing, measuring, and managing customer based brand Equity. Mark, J., 57, 1-22.

[7] Kotler, P. (2003). Marketing Management: (11 ${ }^{\text {th }}$ ed.). New Jersey: Prentice- Hall, Inc., Eaglewood Cliff, 22-75.

[8] Reichheld, F.F. (1996, March/April). Learning from Customer Defections, Harv. Bus.Rev., 56-69.

[9] Selnes, F. (1998). Antecedents and consequences of trust and satisfaction in buyer-seller Relationships. European Journal of Marketing, 32(3/4), 309-322.

[10] Zeithml, V. A. and Bitner, M. J. (2003). Services Marketing. Integrating Customer Focus across the Firm. Boston: McGraw-Hill Irwin. Relationship between Types of Problems and Customer Responses. Canadian J. Admin. Sci., 13(3), 264-76.

[11] Zineldin, M. (2006). The royalty of loyalty. CRM, quality and retention. J. Consum, Mark, 23(7), 430-437. 